\title{
Cultural Collision and Women Victimization in Buchi Emecheta's The Joys of Motherhood
}

\author{
Mohamed Fathi Helaly \\ Assistant Professor, College of Arts and Science \\ Prince Sattam Bin Abdelaziz University, KSA \\ E-mail: drhelaly_2010@hotmail.com
}

Received: 26-09-2015

Published: 01-03-2016
Accepted: 11-12-2015

doi:10.7575/aiac.ijalel.v.5n.2p.117
Advance Access Published: December 2015

URL: http://dx.doi.org/10.7575/aiac.ijalel.v.5n.2p.117

\begin{abstract}
Buchi Emecheta is one of the most important female writers to emerge from Nigeria. She is distinguished for her vivid description of female subordination and conflicting cultural values in modern Africa. In Emecheta's The Joys of Motherhood Nnu Ego, the protagonist, has to suffer as a wife both in the tribal environment in which she was born and the urban community in which she is compelled to live the rest of her life. Nnu Ego has to suffer because these two environments have different cultures. She falls a victim of the tension of the collision of these two conflicting cultures. This collision occurs between the institutions of the traditional Ibo society and the institution of Western Europe. The hardships that Nnu Ego experiences are the result of the clash between the Ibo traditions and the colonized Lagos. It is a clash of traditions, values and priorities. Nnu Ego is victimzed because of what the village (Ibuza) community demands her to do, on the one hand, and what the rules of a European political regime requires her to be. She finds herself in a predicament as she has to assume different roles in accordance with the values of the surrounding communities in which she has to live. She escapes from Ibuza because she is not accepted as a wife who cannot produce children. She flees to the distant city of Lagos to start a new life with another husband with the hope of fulfilling her dream of carrying children. This dream is rooted in the cultural values of the Ibo society where motherhood is the primary source of female self- esteem and public status. In Lagos Nnu Ego fulfills her dream of motherhood and begets a lot of children but the pleasures associated with motherhood are negated by the difficult economic conditions of her new urban community and its norms and values. She has to work day in and day out as a street-side peddler to sustain her children because her husband is away working for the colonizers most of the time. Nnu Egos has to adapt to the system that is devastating to maintain her role as a traditional wife and mother regardless of the fact that this system works against the success of that role and ends up with contributing to her subjugation.
\end{abstract}

Keywords: motherhood, victimize, predicament, traditional, colonized, urban, tribal, clash, collision, subordinating, conflicting

\section{Introduction}

The subject of women victimization and oppression has been of a considerable concern for many female writers throughout ages. Generally, women are considered as weaker and less powerful than men in every society around the globe. Women see themselves as the subject of men's malpractice and subjugation. This culture of subjugating women is worldwide. It passes on from one generation to another. In a multinational and multiethnic society, a white woman is oppressed by white men, a black woman is oppressed at two levels: she is oppressed because she is black and she is also oppressed by black men because she is a woman. Even within the same community a colored woman has to undergo oppression from both black and white people because she is a hybrid; she is neither black nor white. Moreover, throughout ages, women have been suffering from inequality to men as they have had fewer legal rights and career opportunities. Their main jobs in every society are wifehood and womanhood. They have been discriminated against and this discrimination has been a custom that passed from one generation to another.

On the other hand, in colonial societies the dilemma of women is even greater as they have to undergo the different changes brought by colonialism. Colonialism has brought a new culture with it. This culture has had a devastating impact on the life of the colonized lands in general and on women in particular. Many countries in Africa were under European colonization and Nigeria was one of them. It is a general practice that Colonialism forces native populations to adapt and adhere systems foreign to theirs. It threatens the values and traditions of the native traditional culture. The influence of colonialism touches all levels of societies both the family as well as the individual. Generally, African women have to obey the culture and traditions of the land on which they live.

World War II had its devastating impacts on the colonized nations including many African countries. In fact, the African people had no business in this war and they did not create this war. However, they were forced to join the armies of the colonizing nations. As a result, this war has its immediate devastating influences on the economic and social lives of the colonized peoples. There were many drastic consequences on the lives of both men and women in the 
colonized nations. In Africa, the situation was not an exception. African men were forced to leave their families to join the colonizing countries. Of course, African women had to take responsibilities toward their families while husbands were away fighting for the colonizing armies. They had to act as mothers at home and fathers outside the houses. Thus, the switching of roles among men and women, husbands and wives had become a feature in the colonized African countries. Moreover, the colonial powers brought with this new a new culture and a new lifestyle. The result was felt at all levels in the society.

During the colonization period in Nigeria, many changes were taking place and the native population had to come to terms with the western values and life style. People found themselves in a dilemma to either assimilate this new life style and culture or cling to their traditional values. Of course, the many changes brought to the s society also brought unfavorable consequences that destabilized the already existing ruling systems: The European colonization brought modernization; but the notion of modernity was problematic as it represented a thread to the traditional African values". (UKessays. 2014, p.5) There, a cultural clash between the two systems was inevitable. Of course, this clash had created a great disorder in the cultural, social, economic as well as the political systems especially for women.

In Nigeria, like in many other countries, men subjugated women. They are victims of subordination in their society. With the coming of imperialism, women have become victims of the newly imported society. A society where African women are required to continue performing traditional duties and responsibilities. As Derrickson puts it "Nigeria's transition from a tribal culture and a tribal moral value system of a Western capitalist system with all its benefits has occurred at the expense of women who have exchanged one form of patriarchy with another, while being stripped of former privileges and denied the right to new ones". (Derrickson.2002, p.5)

The Joys of Motherhood is a novel set in the British colony of Nigeria in the 1930s and 1940s. It details the life of an Igbo woman named Nnu Ego who escapes he shame of a childless first marriage by fleeing to the distant city of Lagos to start a new life with a second husband. That is Nnu Ego is compelled by the tradition of her native culture to move to another society with a different cultural background. Here, the protagonist has to undergo the overbearing patriarchy of both the tribal society as well as the colonial society while she is performing her role as a wife and a mother.

In the novel, Buchi Emecheta is concerned with the conditions of women and their endeavor to achieve self-fulfillment. In doing so, she explores both the positive and the negative impacts of colonialism on women in Africa in general and Nigeria in particular. She is very much concerned with exploring he predicament of women as a result of the imprisonment between the traditions of society and the modernity brought by colonization.

In the present study, he Joys of Motherhood will be looked upon from both a colonial as well as traditional perspectives. Here, Emecheta is touching upon a very crucial issue regarding the existence of the African woman in two different cultures. She wants to underscore how colonialism has caused distortion in the traditional culture of the African woman. In writing The Joys of Motherhood, Emecheta could create a story of Nigerian women where colonialism and traditionalism are hosted in two different places namely: the traditional Ibo society in Ibuza and the urban society of Lagos. The former practices patriarchy maintaining a traditional and cultural power associated with the ability of producing children especially male children. The latter practices social as well as economic pressures that culminates in undermining family ties.

Taking Nnu Ego as a model of the African woman who is torn between two cultures, the present study attempts to answer the following questions: In what ways are Nnu Ego's experiences and responses to events in her life representative of the condition of the Nigerian woman under colonization? To what extent do cultural expectations contribute to her plight? How does Emecheta provide a true representative of the Nigerian woman conditions? Is Nnu Ego representing the state of affairs for all African women or only the Nigerian women? How does Nnnu Ego convey her message about the condition of the Nigerian woman through her own experiences? How is Nnu Ego is victimized by her first husband, her father and the community in Ibuza because of her inability at child producing? How far she is also victimized by her second husband, the colonizing economic, social and cultural systems as well as by her own children? To what extent Nnu Ego's adherence to the traditions of her Ibo culture contribute in victimizing her?

Nnu Ego's journey through life is characterized by a number of continual tragedies that reflect the tragedies of the modern African woman in general and the Nigerian in particular. In her struggle, Nnu Ego represents the Nigerian woman's struggle in defending her female status. Emechta uses her personal experience as a Nigerian woman to express her contempt toward female subjugation underscoring the oppressive systems perpetuated by Nigerian culture. As Nadaswaran points out "In this novel Emecheta demonstrates how the traditional point of view of a woman's role in precolonial Nigerian was not applicable during the colonial period... As the Nigerian society changes, women are still expected to play traditional roles as wives, economic provider and nurtures. This change brings about many problems for them". (Nadaswaran.2012, p.146)

In The Joys of Motherhood, Emecheta wants to underscore what it means to be a woman and a mother in the Nigerian society during the 1940s. She wants to explore the dilemma of the rural and urban woman whose efforts to come to terms with the situation in which she finds herself is overwhelming. Emecheta uses her personal experiences as a Nigerian woman whose life is distorted as a result of living between two cultures. "Emecheta lives between two cultures. Her African culture makes her portray females as traditionally subordinate but, on the other hand, she is exposed to western values which influences how she portrays her female characters". (Chikodili. 2011, p.24) 


\section{The Precolonial society of of Ibuza}

Ibuza is a village where people live in a rural environment. Such an environment has its own traditions, customs, values and norms at the economic as well as social levels. According to traditions in Ibuza, women are made to understand that men are the source of power and the masters of the houses. Women are also made to understand that they are brought up to obey and fulfill men's needs and desires. Moreover, women are considered as properties that can be bought and sold. They can be sold to men who can pay the bride price to their families. However, the price can be given back to the husband if a woman fails to produce children. Mango Beti puts it "The bride price becomes the chain that a woman is tied by". (Mango. 1989. 4) in Ibuza, women are victims of male dominance. They are considered as properties of men. As Ketu H. Katrak states "The control of women as property is not only biological; it is the root economics, as evident in the Igbo custom of bride price she will fetch on marriage and 2) her ability to bear children, preferably sons" (Katrak.1989. 159).

In a tribal society such the Ibo society, a woman is free but is not allowed to marry on her own. She cannot make her own decision regarding marriage and maternal life. Moreover, she is not allowed to make any decision associated with raising her children. In Ibuza, the role of men is different from their role in an urban community. Here, in Ibuza, a man's role is defined by his culture and his people while his role in an urban community is defined by outsiders (colonizers). In the tribal society, men seek to enforce the traditions of the land. Such tradition has been there for generations with no change at all'. (Emecheta..1979. 46)

In the precolonial tribal society of Ibuza, both men and women have their own share inside and outside their houses. Both participate actively in the economic and political systems of the village. Women represent some force in the society's agrarian economy. They play a certain part in the operation and management of the village market. The husband is the primary sustainer but not the only sustainer as the wife is allowed to have a job of her own to earn money to contribute in the household. It is also in Ibuza that the system allows women to work together and to interact with each other. Of course, such interaction is crucial as it enables them to act both as mothers and wives it also gives them emotional support. "The pattern women construct establishes an important contrast between traditional Ibo society and colonial Lagos”. (Derrickson.2002, p.11)

According to the traditional Ibo society, child bearing is one main trait of a successful maternal life. It is the main trait that allows life to continue between a couple. It is considered as a dream of longevity. It is not only a pleasure but also an obligation. A baby, especially a son, is the greatest desire on the part of both the husband and the wife. It is their means to fulfill their dream of being remembered after death. A woman without children is worthless. A Mango Beti puts it "Having a baby is a proof that can make a woman pregnant and it is a testimony of manhood". (Mango. 1989, p.5) In Ibuza, having children is also a source of power, success and self-esteem. According to the Ibo culture, "a child is part of a woman identity, the only symbol of hope, success and self-fulfillment for women. Fertility is a determinant factor of a woman's status and reputation". (UKessay.2014, p.6)

\section{Nnu Ego's family Background}

Ona, Nnu Ego's mother, is the daughter of a powerful father. He is a great chief in the community of Ibuza. Ona is a very assertive character. As she is a girl, she refuses to get married to any husband. However, according to the culture of Ibuza, a girl is to get married to achieve womanhood. She must get married to become a mother of sons and to do this successfully, she has to accept the authority of her father and husband. A daughter is not allowed to make my decision regarding marriage and children. In Ibuza “

Husbands dominate their wives and fathers dominate their daughters ensuring a system of perpetual subjugation of women. Here, women are valued only for the money they bring to their fathers through their price. Girls have no choice in whom they marry and that sexual relationships are unromantic because fathers sell their daughters to the higher bidder". (Nnormele.2002, p.179)

Ona gets married to Agbadi and soon she bears a baby. Once she gets pregnant, she is forced to choose between her father and her husband. She remarks "My father wants a son and you (Agbadi) have many sons. But you don't have a girl yet. Since my father will not accept my bride price from you, if I have a son he will belong to my father but if a girl, she will be yours. That is the best I can do for you". (Emecheta.1979, p.25) Here, it is a society that values child bearing especially sons. Ona gives birth to a baby girl and Agbadi refuses the baby to live with the father. After Ona's father death, she has to move to live with her husband Agbadi.

In the course of time, Ona dies while giving birth to her second child. In her deathbed, Ona urges her husband to allow her daughter to have a life of her own. Ona asserts that, as Mclean remarks "a real woman is someone whose feelings of worth do not depend on fulfilling the expectation of a father and a husband". (Mclean.2014, p.15) Ona pleas her husband to give freedom to her their daughter "Nnu Ego" to choose a husband of her own. She urges him saying "Please don't mourn me too long; and see that however much you love our daughter Nnu Ego, you allow her to have a life of her own, a husband if she wants one. Allow her to be a woman". (Emecheta.1979, p.28)

Ona dies broken hearted leaving a will to be fulfilled. She does so because she knows that the culture of her society strips girls of their freedom to lead an ordinary life like men regarding their choice of the other mates. Eventually, she dies without knowing that her will never be fulfilled by her husband. She dies because she wants to defy the tradition and the cultural values and norms that govern her community. As Willeys puts it "Emecheta's message is that Ona is to 
die because she is defying tradition by asking Agbadi to give their new born baby girl full freedom to choose a husband by herself and to make her own decision in the future". (Willey.2010.158)

\section{Nnu Ego's Predicament Features of Victimization in Ibuza)}

Unlike Ona, who has great confidence in herself, Nnu Ego the daughter lacks this natural confidence and fails to defy the society as she is unable to produce children. Generally, Nnu Ego appears as a woman in despair suffering from both mental and physical agony because of the situation in which she is cast. Her actions are governed by two different worlds and her predicament lies in the contrast between two conflicting cultural codes. She lives in a traditional society where people adhere to the cultural norms of the traditional society of Ibuza. It is a society where family ties are strong and familial support is abundant through farming. However, Nnu Ego is compelled to leave the old society to a new capitalist society in the urban city of Lagos as a result of her inability to produce children. In Lagos, there are no family ties within the same family and no land to be cultivated and women have to play a crucial role in sustaining their families.

In Ibuza, Nnu Ego is an object of subjugation. She is imprisoned in the Ibo cultural traditions especially those associated with childbearing. She is to live according to the standards expected of her. Through Nnu Ego's journey, Emechata wants to show the influence of the traditionalism and how it is responsible for the situation of the Ibo woman in general. According to the values in Ibuza, a child is part of a woman's identity and the only symbol of success and self-fulfillment for women. "A woman without a child for her husband was a failed woman". (Emecheta.1979, p.62) Here, the culture dictates that man is to give food and children to a woman and a woman is to cook, bear children and look after them. That is to say having children in Ibuza is the primary source of a woman's self-esteem.

Nnu Ego is the daughter of the great chief Agbadi. She is brought up as a princess adhering to the values of Ibuza to be a successful wife and mother. She gets married to an Ibo man called Amatokwu. Despite being a true lover of Nnu Ego, he rejects her because she is not able to produce children. Moreover, Nnu Ego is rejected by both her father as well as her community because of her childlessness. She has to suffer in her life and she becomes emotionally unstable. Nnu Ego cannot achieve integrity in Ibuza and she has to suffer the disintegration of her first marriage because she remains without children for two years. "It is in Ibuza that a childless marriage is not recognized. When a woman is virtuous, it is easy for her to conceive". (Emecheta: 1979, p.30) Thus, Nnu Ego is rendered a victim as a result of her bareness.

Being unable to conceive, Nnu Ego finds herself in a pitiable situation. She has to undergo a drastic change from a powerful daughter of a powerful man to a helpless wife, Nnu Ego lacks the natural confidence to defy the society because she fails to be a true woman. Consequently, her marriage deteriorates. She admits the defect on her part in telling Agbadi "I am sure the fault is my side, you do everything right". (Emecheta.1979, p.31) In this regard, Nicole Willeys points out "Because Nnu Ego and her culture place a premium on motherhood, she is easily destroyed by her inability to get pregnant and she lives unrestlessly in Ibuza and is rejected by both the people and the traditions". (Willey.2010, p.162)

In Ibuza, the traditions dictates that giving birth to children is a great pleasure for both parents as a baby is their dream that fulfills their dream of longevity. According to the traditional and cultural expectations that a woman's ultimate joy and worth are measured by motherhood were a source of unbearable pressure on a barren wife like Nnu Ego.. Nnu Ego believes that the only way to be happy is to be a mother. She develops an impulsive desire to be a mother and this desire is stimulated by her vision of the value of children in the future. She tells her father "when one grows old, one needs children to look after one. If you have no children, and your parents have gone, who can call your own". (Emecheta.1979, p.38) Nnu Ego is also guided and governed by the norms of the society where children are a source of public acceptance and self-esteem. Derrickson remarks that "Nnu Ego's simple dream of becoming a mother is a dream rooted in cultural values of Ibo society where motherhood is the primary source of a woman's self-esteem and public status". (Derrickson. 2012, p. 2)

Another feature of women victimization in Ibuza is that of polygamy which represents another means for men to control women. In Ibuza, the system dictates that if a wife fails to be a mother the husband is allowed to have another wife and take back the bride price he has paid. Amatokwu, Nnu Ego's first husband, practices some violence on Nnu Ego because of her failure to bear a child. He beats her mercilessly. He says to her "Let her go ....she is as barren as a desert". (Emecheta: 1979:39) Eventually, he sends her back to her father Agbadi and he gets married to another wife who is able to conceive. "Nnu Ego sacrifices her health and selfhood in the pursuit of failed traditions capsulated in the idea of motherhood. She is an object on which society heaps its unfair practices and demands". (Nnormele.2002, p.182)

\section{The Impacts of Colonialism on the Life of the People in Nigeria}

The Joys of Moherhood is concerned with the influence of colonization on the tribal people of Africa especially in Nigeria. With the coming of colonization, people have to face a lot of changes. However, the change in culture is the most crucial. In Nigeria, the native people have been forced to adapt and adhere to systems foreign to theirs. This newly brought system has threatened the values and traditions of the native traditional culture. The impact of colonization can be seen at all levels of society: at the family level as well as the individual level. It gas made it difficult for the natives to adapt to the changes in the colonial society. Bhabha points out that "members of a postcolonial society have an identity which has been shaped jointly by their own unique cultural and community history, intertwined with that of the colonial power". (HelpMe.com/view15April2014) Generally, a person's identity is shaped by a sense of who he is in relation to the surrounding larger community. In Ibuza, though women are subdued by men, husbands are the main providers for their families. However, in Lagos the impact of colonization has switched roles and the situation is 
different as husbands sometimes are unable to provide for and sustain their families in a way to meet their needs due to the meagre income they receive from their colonial employers. Husbands are unable to cater adequately for their families. As a result, the structure of the family is gravely influenced and this leads to the gradual disintegration of cultural values. Nnormele remarks "the legacy of imperialism is that in its attempt to civilize African culture, it took away the right that African women had in its precolonial society. Life is supposed to be better in post-colonial era, but the conditions of women is even worse". (Nnoromele. 2002, p.189)

In Lagos, women as well as men have to abandon their own traditions and to accept the new system and both remain torn between the codes of the two cultures. In the urban city of Lagos, men are compelled to live under submission and this is why their role as husbands is undermined. In addition, as fathers, their authority over their families is also undermined as they work as servants for the colonists. They serve in the houses of the white Europeans. They have to do the humiliating tasks to maintain their importance to the colonial masters. Furthermore, the impact of the colonial power can be also seen on the physical appearance of the native people of Lagos. The nature of the work for the whites does not require the physical strength required by the nature of work in Ibuza. Working as servants in the houses of the colonists turn them to be womanlike. Jetu Katrak sums up the impact of the new system stating:

The local economy was indeed a major force in contributing to the subjugation of women ..... while African men were allowed to enter the formal economy of colonial Nigeria by acquiring jobs that paid standard wages, African women were executed from this share and were edged instead into informal and highly unsuitable economy of street side peddling”. (Katrak.1988, p.159)

During the precolonial period in ,Nigeria, women were allowed to work on farms with their husbands. However, with the coming of colonialism, the traditional roles of women have changed and underestimated by men. The status of women has become at stake with the introduction of capitalism as new economic system. The colonizers have modified the roles and status of both gender. Women have been excluded from any paid work. As a result, women are forced to comply with the new system. As Derrickson puts it:

Colonialism destroyed the basis on which African women coalition were formed, but it also regulated women to the ranks of such destitution that been collective action was no longer a possible means of organization. Survival became a competitive game that was best played on one's own". (Derrickson.2012, p.10)

Thus, colonialism forced native people to adapt and adhere to systems foreign to theirs. It threatens the values and traditions of the native traditional culture. The influence of colonialism touches all levels of the society both the family as well as the individual. Nnu Ego's predicament lies in her inability to embrace changes in the colonial society.

\section{Nnu Ego moves to Lagos}

Nnu Ego is the most complex of all characters in The Joys of Motherhood. As Fishburn remarks "It is through Nnu Ego's life and body that the battle between tradition and colonialism is played out. Nnu Ego's own traditionalism while she lives in Lagos is representative of war between Ibo and Western culture". (Fishburn. 1995. 114) In Ibuza as well as in Lagos, Nnu Ego tries her best to remain a good woman. She adheres to the traditions of her native culture. Yet, this adherence does not help her when she is forced to move to Lagos. She is unable to have enough confidence to withstand the changing conditions of a conflicting culture in the colonial society.

\section{Nnu Ego's second marriage}

Having failed to be a mother in Ibuza, Nnu Ego is forced by the tradition of her culture to get divorce from her first husband Amatokwu. Her father has to give back the bride price to the husband. Meanwhile, Agbadi. The father, has to find another husband to his divorced daughter. She lives restlessly in Ibuza and is rejected by both the people and the traditions. Eventually, she leaves her native town for the urban city of Lagos to a new husband that she has never seen. That's she is forced to leave her traditional homeland because of circumstances beyond her hand. Patrica Mclean points out that "Nnu Ego's journey to Lagos represents the urban drift that brings about the breakdown of traditional Ibo society", (Mclean: 2003: 3)

Nnu Ego is sent from her home town Ibuza to live with her new husbands in the capital Lagos. She is disappointed upon seeing a man whose appearance she does not like. This man is shortly going to be her husband. He is a wash-man working for a British family. Nnu Ego is shocked to see that her perception of the man as a male African and what he is supposed to be broken:

She fought back tears of frustration. She was used to tell wiry farmers with rough blackened hands from farming, long, lean legs and very dark skin. This was one short, the flash of his upper arm danced as he moved about jubilantly among his friends and that protruding belly. She despised him on first night". (Emecheta.1979, p.44)

\section{Nnu Ego's first impression upon seeing Naife}

Naife is originally an Ibo man who has moved to Lagos to work as a servant to a white family. He is not like the other Ibo men. The impact of the environment on the appearance of Naife is clear. "His hair, unlike that of men at home in 
Ibuza, was not closely shaved; he left a lot of it on his head, like that of a woman morning for her husband..... Why, marrying such a jelly of a man would be like living with a middle aged woman.” (Emecheta.1979, p.42)

Nnu ego compares her new husband to a woman. She does not like Naife behavior and she sees it as unmanly. She tells him:

If you had dared come to my father's compound to ask for me, my brothers would have thrown you out.....If things had worked out the way they should have done, I wouldn't have left the house of Amatokwu to come and live with a man who washes women' underwear. A man indeed. (Emecheta.1979, p.49)

To Nnu Ego, Naife appears to have more feminine qualities than herself. She considers the nature of his job as feminine and emasculating. Naife's body is soft and sweet smelling. To her, he is no longer a man due to his physical appearance and his insistence and willingness to work under the European people as a laundry man. The impact of the colonial power can also be seen on the physical appearance of the colonized men in Lagos. Unlike the nature of the tasks in traditional Ibuza, the work in Lagos does not require that physical strength. Nnu Ego describes Naife once she meets him in Lagos as "a man with a belly like a pregnant cow, wobbling to this side and then to that. The belly, coupled with the fact that he was short, made him look like a barrel". (Emecheta.1979, p. 42) In The Joys of Motherhood, Emecheta uses Naife to detail how colonialism affected the African male from a female perspective.

The conditions of Naife's job as a laundry man are so degrading and humiliating that his wife surpasses him as a provider for the family. Of course, this switching in roles is a direct result of colonialism on the social and economic life of the people under capitalist economic systems. As Mathew Craft points out "the impact of colonialism is clear on Naife's personality and it represents a symbolic castration of him as a colonized male". (Craft.2013, p.1) As a man and husband, Naife wants to fulfill his roles, but his desire to be dominant clashes with his immediate condition as a servant working for a white family as a laundry man. He likes this work and is not willing to strive to maintain his role as a family man.

Here, Naife's role is determined not but by culture and tradition but rather by the colonizers. Unlike in Ibuza, where man seeks to enforce the tradition of the land and he is the main provider for the family, in Lagos a husband's role remain undefined. It is true that he is a sustainer of the family but not the primary sustainer as women are to contribute to the income of the family. Naife abandons the values of his tradition and culture and goes to adopt a new culture where he has to disregard his original culture with its values. Of course, getting adapted to this new culture means that he is more European and less African. The nature of this job that Naife liks is considered as shameful and humiliating by his fellow countrymen. Naife's countrymen consider him as "a pariah who chose to sell his manhood to placate the white man; yet the cost of this sale does not yield a commensurate benefit because to the white man he will always be just a servant, never anything more". (Craft.2013, p.3)

The environment of the colonial society makes it difficult to keep family ties. It spoils the African man's sense of responsibility. Unlike in Ibuza, where husbands never leave their families, in Lagos there are no family ties to combine the father, the mother and the children. The humiliation inflicted upon the husband is reflected on their families especially the wives. Simply, wives are victimized by their own husbands because of the nature of the colonizing system. Nnu Ego sees Naife's work as a slave. "Naife's slavery put Nnu Ego in double jeopardy; at home he becomes the victimizer". (Ogunyemi.1996, p.355)

Thus, in the context of society of Lagos, it is difficult for husbands to maintain that sense of responsibility that they previously acquired in their tribal community. Women are victims that are victimized by their own husbands as they (men) are unable to provide for their families on a regular basis. They are away for long and mothers have to work to secure a better livelihood. Men are either working as servants for white families or are forced to join the colonizers' army to fight in wars as mercenaries. On the other hand, women are forced to live their houses and go to the market to work to be able to sustain their families they can be street peddlers or do any business that can be a petty trade.

In Lagos, women and men have to abandon their own tradition and adapt to the new system and both remain torn between the two cultures. Here in Lagos, men are forced to live under submission and this is why they are not able to enforce a familial or cultural system of patriarchy the husbands' authority over his family is undermined as e remains a servant under a colonial system. It is a system where things are changing rapidly to coexist with such changes, women have to adapt themselves to this new world with its culture and values. Nevertheless, they try their best to adhere to their original cultural values. Yet, this adherence does not help them in this new world of Lagos. Here, the switching of gender roles has become one feature of the society of Lagos.

\section{Nnu Ego as a mother in Lagos}

In Lagos, Nnu Ego regains confidence in herself as a woman capable of childbearing. Moreover, she does not like Naife nor the new urban community of Lagos and she is overjoyed when she discovers her ability to produce children. Soon, Nnu Ego conceives and is in the way to motherhood. Now, she feels like "a real woman" who has a feminine identity. "Her new found ability to bear children does not satisfy her maternal longings and fulfill social expectations, it provides her with the only form of feminine identity she is permitted, or can contemplate: motherhood". (Mclean.2014, p.17) Conception is a dream of longevity and having a baby is a proof that makes of a woman pregnant. It is also a testimony of motherhood. 
In Lagos, Nnu Ego, finds herself living in a new environment that has a culture different from her old culture. It is a rapidly changing world. Here, Nnu Ego has to adapt to a new form of pleasure to motherhood. As a mother, she has to struggle to provide for her children under a new colonial system that makes it difficult for her to find a sufficient support by a husband who is forced to be away from his family most of the time. Nnu Ego's concept of motherhood is liable to change according to the culture for the place she is liable to change according to the culture of the place she is compelled to live in. Here, she has to be a mother at home and a father outside it. She has to assume the traditional role of a man as a provider and breadwinner to raise her children.

Nnu Ego has to fight to maintain her family well-being. She takes upon her shoulders to meet her family's needs regardless of the hardships she has to face. "She has to fight to exist and breathe in her own house". (Beti.1989, p.4) Despite the lck of support and the meagre income of Naife, Nnu Ego refuses to something else other than a dedicated mother. She has to cope with a life of poverty and sacrifice. She realizes that it is inevitable for her to find a way to support Naife's insufficient income. She has to work a street peddler to provide for the lack of a good provider for the entire family. As Erasure points out "the colonial influence challenges the communal value system that once defined the Africans. This leads to the gradual disintegration of cultural values and here the family if affected profoundly. Nnu Ego has to struggle to hold the family together in Naife's absence and his meagre allowance of 20 pounds is barely able to sustain them". (Erasure.2012, p.3)

In Ibuza, females have been brought up to be good wives and good mothers. They are to meet their society expectations. Forced to move and live in another society and a different culture and its values. In Lagos, she has to face many hardships to overcome challenges. As Nnoromele puts it "To survive in her world, Nnu Ego must acquire foresight, self-reliance, creativity and flexibility to adapt to changing realities. She finds herself living with an unsuitable husband and poverty that she has to assume what society expects from her". (Nnormele.2002, p.184)

Nnu Ego is blessed with a lot of children including sons and she has a firm belief that her children are her joy in a community where poverty and hardships prevail. She devotes her entire life to her children. Happily, she indulges in trade and business and gains some self-esteem early in the novel when she earns a fair amount of profit from her petty trade. However, the restrictions imposed by the society make it difficult for her to continue. The impact of colonialism on women in Lagos is devastating. Nnu Ego assesses the injustice of her life in Lagos as follows:

It was not fair, she felt, the way men cleverly used a woman's sense of responsibility to actually enslave her in Lagos, where she was faced with the harsh reality of making ends meet on a pittance. Was it right for her husband to refer to her responsibility? It seemed that all she had inherited from her agrarian background was the responsibility and none of the booty. (Emecheta.1979, p.137)

Thus, it is clear that Nnu Ego's predicament lies in her obligation as a woman brought up in a rural tribal community and forced to live the rest of her life in an urban modern community. She appears in despair suffering both mental and physical agony at her situation as her actions are governed by two different cultural codes. As Nnormele puts it:

Nnu Ego's sense of disequilibrium is the result of the contrast between two conflicting worlds. The old world 9iBO0 is one in which men romanced their wives, women supported their families through farming, family ties were strong and emotional and financial support abundant. In contrast, the new world (Lagos) is bewildering and tiring. There is no room for extended family support, no land to be owned or cultivated, and women have to enter the world of trade to find money". (Nnormele.2002, p.183)

Nnu Ego is distracted as a result of the tension between the traditional Ibo society and the new colonial European society. Here, in Lagos the values of the British culture of the home land. Women are victimized by the society as a result of their inability to exist between what their own traditional cultural demand of them and the rules of the colonial culture require them to do. Their predicament lies in their inability to show commitment to their traditional duties under a new economic capitalist system. Really, it is a system that has an overwhelming impact of the well-being of traditional women.

In Lagos, Nnu Ego becomes the mother of many children. Yet, she is denied the maternal pride that mothers attain in Ibuza. She falls prey to the capitalist system that promotes Western values of individualism over domestic responsibility. Nnu Ego is victimized by this new system where the tribal glorification of motherhood is no longer valued and no longer rewarding. Despite fulfilling her dream of motherhood, Nnu Ego never feels comfortable. She expresses her indignation toward the community of Lagos through how her situation would be if she were in Ibuza. She contends "at home in Ibuza I would have had my own hut and would at least have been treated as befitting my position”. (Emecheta.1979, p.137) Willey states “Nnu Ego succession of children, and her traditional equation of children with wealth versus the realities of Lagos, depicted painfully the struggle between traditional and colonial values". (Willey.2002, p.162)

In Lagos, again, Nnu Ego has to struggle to feed her children according to the fluctuating level of poverty that she has to face. Unlike in Ibuza in Lagos, the system does not allow women to have regular jobs and, as a result, they have to depend on their husbands. Nnu Ego does her best to sustain her children while Naife is away either working for a white family or taken to war to fight for the British. As Derrickson puts it "Nnu Ego's prompt capitulation renders her a victim as an African women in a colonial capitalist Western society. Derrickson remarks "Nnu Ego's situation is shaped by a harsher economic setting where poverty is not alleviated by the blessing of children because children are too much of a material liability in a place of such limited resources". (Derrickson.2012, p.7) 
Nnu Ego's dream of motherhood has been fulfilled but it is negated by the difficult economic conditions of the new urban environment. She believes that the only way to be happy and fulfilled is the traditional role of motherhood. In fact, Nnu Ego's desire to be a mother is supported by a vision of the future value to her. She once tells her father "when one grows old, one needs children to look after one. If you have no children, and your parents have gone, who can you call your own". (Emecheta.1979, p.38) Nnu Ego knows that children are important for her in life and after death. Nnu Ego devotes her life to her children anticipating that when she gets old, she will reap the result of her devoted motherhood, dreaming that "her old age will be happy and that when she dies, there will be somebody left behind to refer to her as a mother". (Emecheta.1979, p.54)

Nnu Ego tries her best to adhere to traditions in a modern setting. She wants to continue as a woman of Ibuza in Lagos. In Lagos, Nnu Ego does her best to find sources of income to feed her children. However, the money she gets can not suffice. She appears as a dedicated mother. In a moment of reflection se reveals:

I was born alone, and I shall die alone. What I have gained from all this? Yes, I have many children, but what do I have to feed them on? On my life, I have to give them all. And if I am lucky enough to die in peace, I even have to give them my soul". (Emecheta.1979, p.186)

While in Lagos, Nnu Ego does not have that sense of pride and recognition as a mother in the same way that mothers have in Ibuza. She is denied this sense and is victimized by the colonial system where the tribal pride of motherhood is no longer valued and no longer a source of public esteem. She lives under a system where "poverty is not alleviated by the "blessing" of children because children are too much of a material liability in a place of such limited resources: (Derrickson.2012, p.7)

\section{Victimization by the bad work condition for women in Lagos}

Unlike in Ibuza, where women work side by side with their husbands and other women. The system in Lagos makes it difficult for them to share their men any kind of work. A woman in need has to find some business that isolate her from other working women. Of course, this prevents her from having sound relationship with other women in her community. Nnu Ego resorts to the business of petty trading out of the increasing demands of her children. Her need for money keeps her in the street. Of course, such kind of work never provides any emotional support either between working women or between women and men. As Derrickson points out "The economic stricture of a male-controlled economy and Nnu Ego's own attempt to play according to the rules of her newly Westernized setting enslave her in a role in which she is prevented from forming useful relationships with the women around her". (Derrickson.2012.12)

\section{Polygamy as a feature of women victimization}

Polygamy is another feature of women victimization both in Ibuza as well as in Lagos. In the traditional Ibo society, polygamy gives some extra power to the status of women as it allows them to cope with the burden they have to share their husbands. In Ibuza Nnu Ego has had to be a co-wife because of her inability to bear children in her first marriage. She has had to accept the status of a co-wife though she has not liked it. In Lagos, with her second husband and after getting a lot of children Nnu Ego has to be a co-wife again after Naife's brother death. According to traditions in Ibuza, he has to marry the widow of his dead brother. Now, Nnu Ego is the senior wife of Naife. In Ibuza, a senior wife has certain privileges that are denied in Lagos.

Adaku, Naife's second wife, comes to live with Nnu Ego in the same room apartment. Nnu Ego is not happy about being a senior wife in Lagos. She remarks "I can understand the value of being a senior wife in Ibuza, not here in Lagos. It does not mean a thing”. (Emecheta.1979.134) Nnu Ego's new status as a co-wife requires her to engage in sacrifice and self-restraint. In other words, she is not happy with this new status as it requires her to play of the responsible senior wife without offering her the same benefits that once accompanied that role under the tribal system. As Derrickson remarks "Nnu Ego is left without the rewards that a senior wife in Ibuza has. Her predicament as a woman is exacerbated by the fact that the capitalist system she now lives under requires her to play the role of a senior wife without offering privileges". (Derrickson. 2012. 8)

\section{Adaku as a model of African women}

Adaku becomes Naife's second wife after the death of her husband. Unlike Naife's brother's other wife, Adamkwo, who prefers to stay in Ibuza to going to Niafe in Lagos, Adaku chooses to move to Lagos to live with him. Unlike Nnu Ego, Adaku develops a sense of adaptability and co-existence with new environment in Lagos. She can make for herself in Ibuza as well as in Lagos. She is interested in the future of her children much in the same way Nnu Ego is. However, she is more successful in coming to terms with the new system in Lagos. "All she wanted was a home for her daughters. I was worth some humiliation to keep her children together in the same family". (Emecheta. 1979. 120) Adaku is accustomed to be a co-wife and she tries her best to accept her as such.

Adaku with her children have to live along with Nnu Ego and her children in the same house. She appears as a devoted mother who is willing to give her children the best education. Unlike Nnu Ego, Adaku can keep a balance between traditionalism and colonialism. That is to combine both the traditional value of her native culture with those of the colonial system in Lagos. While Naife is away in war, Adaku sees many serious changes going on around her that make of her a real victim of the surrounding environment with its circumstances. She sees husbands are unable to provide for their families on a regular basis. There are no social bonds to unite families due to the absence of husbands for long and women have to work to secure a livelihood. 
In Lagos, the colonial system makes it difficult for both Nnu Ego and Adaku to share the same house because it denies them the opportunity to occupy regular jobs. Nnu Ego realizes that the well-being of her children is endangered by the existence of Adaku and her children. Due to the absence of Naife most of the time and the lack of financial support by him, both Adaku and Nnu Ego have to suffer and fail to have alliance in the same way that co-wives have in Ibuza. As Derrickson points out:

The rivalry between Nnu Ego and Adaku grows so intense that it drives them apart. The physical separation between Nnu Ego and Adaku is not only suggestive of their loss of political power within the home, but it also signifies the loss of a collective support system within African society. (Derrickson.2012, p.10)

Again, Adaku has to face a lot of trouble. She has to spend most of her time with her two daughters. She feels restless to stay in the cramped space with people who don not like her presence. She says "Everybody accesses me of making money all the time. What else is there for me to do? I will spend the money I have in giving my girls a good start in lifetime... I shall see that they get enrolled in a good school. Naife is not going to send them away to husband before they are ready". (Emecheta.1979, p.168)

\section{Nnu Ego's move back to Ibuza}

Towards the end of the novel, Nnu Ego still appears as a traditional mother clinging to the tradition of motherhood. She sends her sons abroad for education hoping that they will be grateful to her after completing their education. Yet, she is disillusioned by her children. She is deserted by them. While there, Nnu Ego persists with her role as a mother. She refuses to accept the help of other women. Nnormele states "In her obsessive pursuit of motherhood and her inability to see beyond her limited self, she goes on refusing any offer of grace or assistance offered to her". (Nnormele.2002, p.185)

Of course, motherhood has given joy; yet, it has also given her suffering. It has also given her power. However, as the novel progresses and Nnu Ego's children grow up, Nnu Ego's misery is increased. Despite the miserable conditions and the deteriorating financial support, $\mathrm{Nu}$ Ego succeeds in giving her children good education. Now, they are well-grown. Her sons are occupied with education and her daughters are married. Naife is away in the war and she is left with the two young children. She is informed of her father's illness. She has to go back to Ibuza to see her father before death. In a moment of reflection, Nnu Ego reveals how she sees her function as a mother now "I don't know how to be anything else but a mother. How will I talk o a woman with no children? Taking the children from me is like taking the life I have always known, the life I am used to". (Emecheta. 1979, p. 222)

Back in Ibuza, Nnu Ego has to cater for herself as her two elder sons have gone to America for education and her elder daughters are in Lagos with their husbands. Nnu Ego's children are influenced by the urban culture of the colonial society. They are concerned only about their education and are not grateful to their mother as Nu Ego has anticipated before. They do not keep in touch with their mother and never provide financial support to their desperate mother and her younger children. Nnu Ego realizes very late that she is not a person in herself and that her being or status is dependent on her relation to her family. She also realizes that her motherhood is a prison. It is Nnu Ego belongs to her children as she that she is responsible for their welfare even after death. As such, Nnu Ego's relationship with her children is mainly based on traditions and culture. A Gjerde puts it "Nnu Ego feels enslaved not only by love, but by the practical tasks in feeding and nurturing her children. Her love does not grow only from herself, but from a need to follow the traditions and norms for women". (Gjerde. 2007, p. 90)

Feeling useless and deserted by her sons that she hardly ever hears from, Nnu Ego lapses into senility and eventually dies alone by the road. She dies miserably by the roadside. She dies while her children are away. As the story tells "Nnu Ego lay down by the roadside, thinking that she had arrived home. She died quietly there, with no child to hold her hand and no friend to talk to her. She had never really made many friends. So busy had she been building up her joys as a mother". (Emecheta. 1979, p. 224)

Nnu Ego dies alone by the roadside like an animal and this is the culmination of her sticking to the traditional code of motherhood. "Nnu Ego's method of death, according to Ibos, is the worst kind of death. Only animals and outcasts die that way. It is through her obsession with motherhood that Nnu Ego made herself an outcast stronger in her own society". (Nnoromele.2002, p. 188)

\section{Conclusion}

As a whole, Nnu Ego can be seen as a victim at many levels. She is a victim of traditions as well as modernity. She cannot survive whole in either of the two communities. Adherence to traditions could save her in the Ibo society or the Lagos society. Such adherence serves as the catalyst of her victimization. Nnu Ego's ultimate predicament lies in her inability to come to terms with what life could offer in light of traditions and values. She could have done what her mother (Ona) did regarding marriage and maternal life both in Ibo and in Lagos. Yet, she could not resist the society and its tradition regarding marriage and childbearing. In Ibuza, she appeared as a victim incapable of defending her status as a childless woman under a traditional system that considered the likes of her not as complete women. On the other hand, Nnu Ego has been victimized by the same Ibo tradition regarding maternal life in Lagos. While there, she became happy as she became a mother of many children. However, her happiness was not to survive unharmed because of the new system in Lagos which makes of her husband a man incapable of providing sufficiently to sustain his family. 
Though Nnu Ego's victimization has taken different forms, the cultural clash has been the very spark from which other forms have been initiated. She has been victimized by society, her husbands, her father, colonists and even by her children. Though each kind of victimization differs from the others in its intensity and its subject. All of the culminates in rendering her a victim of cultural collision. In other words, cultural collision has been used in the present paper as an umbrella term of the different forms systems, values and tradition that has governed the two societies in which Nnu Ego has lived. Nnu Ego could not survive whole taking from each culture of the two what she could see as appropriate to her immediate status either in Ibo or in Lagos. In other words, she could have defined the Ibo tradition regarding marriage in the same way. Ona the mother. In Lagos, she could have adapted to the system there in the same way Adaku (her cowife) did. To make it brief, Nnu Ego could have taken from traditions and cultures what would have supported her to survive in worlds where sticking to traditions is damaging. She has failed in adopting a survival tactic and this is why her struggle culminates in a very humiliating death after realizing too late that the joys of motherhood has to be the sorrow of motherhood.

Emecheta has used Nnu Ego as a representative of the African woman in general and the Nigerian woman in particular through whom she wants to convey a message that adherence to the tradition under a colonizing system is foolish. Emecheta wanted to underscore that though traditions are values and the very codes that govern the lives of the people of any society, these codes should be questioned and should be liable to change in a rapidly changing world especially when outsiders systems are introduced. Here, Emecheta wants to stress that life can never go smoothly without hassles but adaptability to what this life offers throughout time is the best strategy to overcome these hassles.

By large, through Nnu Ego, Emecheta wants also to point out that the endeavor to adapt to new systems should entail discarding some traditions and values of the old ones, and following those customs that can nurture people and develop their lives. Nnu Ego has failed in taking only what would have promoted her life. She has remained loyal to her husband despite his inability to sustain his family. She failed in achieving integration because of sticking to those traditions that have made her appear as a traditional virtuous wife. In other words, Emecheta sympathized with Nnu Ego and her predicament. She wanted to convey that the African woman is stripped of her human rights to choose a husband of her won and turns to be the object of both men's subjugation as well as that of the colonizers. Nnu Ego has been denied the right to determine her destiny because of her submission and adherence to the values of individualism and the inability to adapt to the new system and what has imposed.

The ultimate destiny of Nnu Ego has been her death by the roadside. Until it was too late in her life, Nnu Ego has realized that she could not achieve the fulfillment she has previously anticipated regarding motherhood and childbearing. She reached a moment of recognition that something has gone wrong in her life. She failed to achieve wholeness through the choices she has made with a clarity of a new vision, Nnu Ego has finally realized that following traditions is unquestionable and that her dream of the kind of motherhood she has anticipated has never been fulfilled as motherhood does not always bring happiness. She has also realized that she should have made different choices in the light of what life has offered in a way to achieve personal existence or fulfillment.

\section{References}

Akujobi, R. (2011). Motherhood in African Literature and Culture. Comparative Literature and Culture. Purdue University Press.

Beti, M. (1989). Perpetue et L'habitude du Malheur. Paris, Chasel.

Chikodili, N. (2011). Thematic Exploration of Buchi Emecheta's The Joys of Motherhood and Second Class Citizen. Faculty of Arts, University of Ilorin.

Chukwuma, H. (2006). Women's Quest for Rights: African Feminist Theory in Fiction. Forum on Public Policy. Port Harcourt, Nigeria. Pearl Publishers.

Mathew. (2013). The Colonized Gelding: Material Violence in The Joys of Motherhood. The Catalyst, 3.

Derrickson, T. (2012). Class, Culture, and the Colonial Context: The Status of Women in Buchi Emecheta's The Joys of Motherhood. The International Fiction Review. University of Alaska Anchorage.

Easure, R. (2012). Review. The Joys of Motherhood. 12 Thursday JUL.

Fishburn, K. (1994). Reading Buchi Emrcheta: Cross-Cultural Conversations. Westport, CT. Greenwood Press.

Gjerde, Si. (2007). The Good Mother: Motherhood as Identity and Resistance in Toni Morrison's Beloved and Buchi Emecheta's The Joys of Motherhood. Unpublished PhD Thesis, University of Bergen.

Katrak, Ke. H. (1988). Womanhood/Motherhood: Variations on a Theme in Selected Novels of Buchi Emecheta. Journal of Commonwealth Literature, 22(1).

Mclean, Patricia. 2003. Buchi Emecheta's The Joys of Motherhood Resist Feminist and Nationalist Readings.

Nadaswaran, Sh. (2012). The Legacy of Buchi Emecheta in Nigerian Womwn's Fiction" The International Journal of Social and Humanity, 2(2).

Nnoromele, S. C. (2002). Representing The African Woman: Subjectivity and Self in The Joys of Motherhood. Eastern Kentucky University. Critique, 42(2). 
Ogunyemi, Ch. O. (1996). Africa, Wo/Man, Palava: The Nigerian Novel by Women. Chicago: University of Chicago Press.

Serafin, A. M. (2000). Motherhood as Seen in Two Works of African Literature. Willa, 9.

The Joys of Motherhood English Literature Essay."Ukessay.com 2013. All Aswers LTd. 112014.

Willey, N. (2010). Ibuza VS. Lagos: The Feminist and Traditional Buchi Emecheta. Journal of the Association for Research on Mothering,2(2).

Young, C. (1994). The African Colonial State in Comparative Perspective. New Haven: Yale University Press. 